\title{
Model Upaya Hukum terhadap Ganti Kerugian dalam Pengadaan \\ Tanah untuk Kepentingan Umum \\ (Studi Kasus Pembangunan Jalan Tambaklorok, Kota Semarang)
}

\author{
Oleh: \\ Nur Adhim, \\ Fakultas Hukum, Universitas Diponegoro \\ nuradhimundip@gmail.com
}

\begin{abstract}
Abstrak
Model upaya hukum bagi pemilik tanah yang tanahnya dipergunakan untuk suatu kegiatan pembanguan kepentingan umum diatur secara khusus dalam Undang-Undang Nomor 2 Tahun 2012 tentang Pengadaan Tanah Untuk Pembangunan Bagi Kepentingan. Bila tidak terjadi kesepakatan antara Panitia Pengadaan Tanah (P2T) dengan pemilik tanah dalam hal pembayaran ganti kerugian maka pemilik tanah dapat mengajukan keberatan ke Pengadilan Negeri dan bila tidak menerima bisa mengajukan upaya hukum khusus berupa langsung Kasasi ke Mahkamah Agung. Hal ini terjadi dalam kegiatan pembangunan Pelebaran Jalan Kampung Tambaklorok, $K$ elurahan Tanjung Mas, Kota Semarang. Dinas Pekerjaan Umum Kota Semarang selaku Panitia Pengadaan Tanah memberikan penilaian ganti kerugian yang dirasakan belum layak dan adil kepada pihak pemilik tanah yang berhak. Berdasarkan hasil penelitian, proses pemberian ganti kerugian untuk pembangunan bagi kepentingan umum tersebut mengalami hambatan, dan faktor penyebabnya yaitu Pertama, pada tahap sosialisasi terdapat kesalahan Detail Engineering Design (DED) dan jangka waktu sosialisasi mengalami keterlambatan. Kedua, pada musyawarah penetapan ganti kerugian, pihak pemilik tanah tidak diberikan kesempatan untuk mengemukakan pendapat dalam menentukan besarnya ganti kerugian, sehingga beberapa pemilik tanah mengajukan keberatan ke Pengadilan Negeri Semarang. Penetapan Pengadilan Negeri Semarang No. 374/Pdt.P/2018/PN. Smg tidak menerima keberatan, dengan alasan tidak dipenuhinya syarat formil berupa tidak adanya Berita Acara kesepakatan musyawarah penetapan ganti kerugian, sehingga pemilik tanah mengajukan upaya hukum kasasi sesuai dengan Peraturan Mahkamah Agung No. 3 Tahun 2016. Upaya hukum kasasi ini merupakan upaya yang pertama dan terakhir untuk mendapatkan keadilan, dan putusan yang dijatuhkan bersifat mengikat.
\end{abstract}

Kata kunci : Pengadaan Tanah, Ganti Kerugian, Model Upaya Hukum. 


\begin{abstract}
Abstrack
The legal effort model for land owners whose land is used for a public interest development activity is specifically regulated in Law Number 2 of 2012 concerning Land Acquisition for Development Utilities. If there is no agreement between the Land Acquisition Committee (P2T) and the land owner in the case of compensation payments, the landowner can file an objection to the District Court and if he does not accept, he can file a special legal remedy in the form of Cassation to the Supreme Court. This happened in the construction activities of the Widening of the Kampung Tambaklorok Road, Tanjung Mas, Semarang City. The Semarang City Public Works Office as the Land Procurement Committee provides an assessment of compensation that is felt to be unfit and fair to the rightful landowners. Based on the results of the study, the process of awarding compensation for development for the public interest experienced obstacles, and the contributing factors were First, at the socialization stage there were errors in Detail Engineering Design (DED) and the period of socialization had been delayed. Second, in the deliberations for determining compensation, the landowners were not given the opportunity to express their opinions in determining the amount of compensation, so that some land owners objected to the Semarang District Court. Determination of Semarang District Court No. 374 I Pdt.P / 2018 / PN. He also did not accept the objection, on the grounds that the formal conditions were not fulfilled in the form of no Minutes of deliberation on the determination of compensation, so that the landowner filed an appeal against the Supreme Court Regulation No. 3 of 2016. The appeal of the cassation is the first and last attempt to obtain justice, and the decisions handed down are binding.
\end{abstract}

Keywords: Land Acquisition, Compensation, Legal Effort Model. 


\section{A. PENDAHULUAN}

Tanah sebagai karunia Tuhan Yang Maha Esa merupakan salah satu sumber daya alam yang penting untuk kelangsungan hidup umat manusia. Bagi bangsa Indonesia tanah adalah sumber kekayaan nasional. Sebagai sumber kekayaan nasional, tanah juga mengandung berbagai macam kekayaan alam yang dapat dimanfaatkan manusia. ${ }^{1}$ Oleh karena itu, penggunaan dan pemanfaatannya harus dikelola secara cermat pada masa sekarang maupun untuk masa yang akan datang.

Seiring dengan perkembangan zaman, kebutuhan manusia akan tanah semakin hari semakin meningkat. Ketersediaan tanah semakin terbatas sehingga membawa suatu permasalahan tersendiri terhadap kepemilikan suatu hak atas tanah karena tanah dianggap memiliki nilai ekonomis dan juga memiliki fungsi sosial.

Keterbatasan tanah karena kebutuhan pembangunan, seringkali kepentingan pribadi atas tanah dikorbankan untuk kepentingan umum. Pelaksanaan pengadaan tanah bagi pembangunan untuk kepentingan umum mengacu pada Pasal 18 Undang - Undang Nomor 5 Tahun 1960 tentang Peraturan Dasar Pokok - Pokok Agraria yang berbunyi: "Untuk kepentingan umum, termasuk kepentingan bangsa dan negara serta kepentingan bersama dari rakyat, hak - hak atas tanah dapat dicabut dengan memberikan ganti kerugian yang layak dan menurut cara yang diatur dengan Undang - Undang". ${ }^{2}$ Melihat perbedaan nilai ekonomis terhadap hak atas tanah yang melekat pada tanah tersebut, dengan demikian maka ganti kerugian atas tanah juga menentukan berapa besar yang harus diterima dengan hak yang berbeda itu. ${ }^{3}$ Perolehan tanah untuk kepentingan umum dilakukan dengan pelepasan hak atas tanah dengan memperoleh ganti kerugian yang tidak hanya berupa uang semata tetapi dapat berupa tanah fasilitas lain yang dapat menunjang kehidupan rakyat.

Masalah pengadaan tanah (dulu, pembebasan tanah) sangat rawan dalam penanganannya, karena di dalamnya menyangkut hajat hidup orang banyak, apabila dilihat dari kebutuhan pemerintah akan tanah untuk keperluan pembangunan. Oleh karena itu satu-satunya cara yang dapat ditempuh adalah dengan "membebaskan" tanah milik masyarakat, baik yang telah di kuasai dengan hak berdasarkan Hukum Adat maupun hak-hak lainnya menurut UUPA. ${ }^{4}$ Proses pengadaan tanah tidak pernah terlepas dari adanya masalah ganti kerugian, maka perlu diadakan penelitian terlebih dahulu terhadap segala keterangan dan data - data yang diajukan dalam menentukan besaran nilai ganti kerugin. Dengan memperhatikan peran dan fungsi tanah dalam kehidupan manusia serta prinsip penghormatan terhadap hak-hak yang sah atas tanah, maka musyawarah harus dilakukan dengan cara yang seimbang oleh instansi terkait dengan melibatkan masyarakat dan para akademisi supaya dapat menghasilkan keputusan yang adil bagi masyarakat selaku pemegang hak atas tanah. Apabila pengadaan tanah melalui musyawarah tidak mendapatkan jalan keluar, sedangkan tanah tersebut akan digunakan untuk kepentingan umum, maka dapat ditempuh dengan cara pencabutan hak atas tanah

\footnotetext{
1 Adrian Sutedi, Implementasi Prinsip Kepentingan Umum Dalam Pengadaan Tanah untuk Pembangunan, (Jakarta: Sinar Grafika, 2007) hlm. 45

2 Bernhard Limbong, Pengadaan Tanah Untuk Pembangunan Regulasi Kompensasi Penegakan Hukum, (Jakarta Selatan: Margaretha Pustaka, 2011) hlm. 21.

${ }^{3}$ Soedharyo Soimin, Status Hak dan Pembebasan Tanah, Edisi. 2 Cet. 2 (Jakarta : Sinar Grafika, 2004). hlm. 79.

${ }^{4}$ Adrian Sutedi, Implementasi Pengadaan Tanah..., log.cit 45.
} 
sebagaimana diatur dalam Undang-Undang Nomor 20 Tahun 1961 tentang Pencabutan Hak Atas Tanah dan Benda - Benda yang ada diatasnya.

Pemerintah Kota Semarang dalam rangka menuntaskan kondisi lingkungan yang kumuh dan meningkatkan perekonomian warga, Pemerintah mengadakan perbaikan kondisi jalan dalam Pengembangan Kampung Nelayan Tepi Air Kelurahan Tanjung Mas Kota Semarang. Pembangunan tersebut sudah direncanakan sejak tahun 2015. Namun, proses pembangunan pelebaran jalan baru dilaksanakan pada bulan Juli 2017 diawali dengan sosialisasi sampai proses pemberian ganti kerugian terhadap pembangunan tersebut. Akan tetapi proses pembangunan pelebaran jalan belum selesai karena masih terkendala beberapa masalah pengadaan tanah yaitu masalah ganti kerugian yang dirasakan tidak sesuai dengan besarnya nilai harga tanah. Terjadi ketidaksepakatan mengenai bentuk dan nilai ganti kerugian antara Dinas Pekerjaan Umum selaku Panitia Pengadaan Tanah dan warga yang menolak uang ganti kerugian yang ditetapkan, disamping pelaksanaan yang tidak sesuai dengan Detail Enginering Design (DED).

Akibatnya, pada tanggal 31 Juli 2018 Pemerintah Kota Semarang melalui Dinas Pekerjaan Umum (DPU) harus menitipkan Uang Ganti Kerugani melalui konsinyasi ke Pengadilan Negeri (PN) Semarang. Namun, pihak yang berkeberatan menolak menghadiri panggilan sidang konsinyasi dari PN Semarang yang akan diselenggarakan pada tanggal 1 November 2018. Surat panggilan sidang konsinyasi disampaikan juru sita PN Semarang dengan nomor 12/Pdt/Kons/PN.Smg, tanggal Senin 29 Oktober 2018. ${ }^{6}$ Pada tanggal 14 September 2018, beberapa pemilik tanah mengajukan permohonan keberatan terhadap besarnya ganti kerugian yang ditetapkan oleh Dinas Pekerjaan Umum selaku Panitia Pengadaan Tanah. Pihak yang berhak tersebut terdiri dari 4 orang yang bernama Ahmad Suhaili, Muchlasin, Achmadi, dan Achmad Busairi. Pada tanggal 17 Oktober 2018 berdasarkan Penetapan PN 374/Pdt.P/2018/PN.Smg, Hakim Pengadilan Negeri Semarang menjatuhkan Penetapan dengan tidak menerima besarnya ganti kerugian yang diajukan oleh pihak yang berhak.

Pada bulan Oktober 2018, permohonan upaya hukum kasasi diajukan oleh pihak yang berhak yang terkena dampak pembangunan pelebaran jalan Kampung Tambaklorok, Kelurahan Tanjung Mas Kota Semarang terkait besaran ganti kerugani tanah yang tidak diterima oleh hakim Pengadilan Negeri (PN) Semarang. Beberapa warga tersebut telah mendaftarkan upaya hukum kasasi ke Mahkamah Agung melalui PN Semarang atas permohonan keberatan besaran nilai ganti kerugian atas tanah yang diberikan pada 17 Oktober 2018 dengan nomor registrasi 374/Pdt.P/2018/PN.Smg.

Pemerintah memberikan kebebasan untuk memperjuangkan hak pihak yang berhak terhadap ganti kerugian hingga upaya hukum kasasi. Meskipun sudah mencapai upaya hukum yang bersifat final, namun putusan kasasi tersebut belum menemukan titik terang baik dari Pemerintah Kota Semarang dengan pihak yang berhak. Sedangkan disisi lain pembangunan pelebaran jalan tersebut belum selesai namun pihak yang berhak belum mendapatkan keadilan terhadap besarnya nilai ganti kerugian hak atas tanah.

\footnotetext{
${ }^{5}$ Anas Wahyudon Masyarakat Tambaklorok, Wawancara Pra Riset, Semarang, tanggal 21 Maret 2019.

${ }^{6}$ http://jateng.tribunnews.com/2018/10/31/warga-terdampak-pembangunan-kampung-bahari-tambakloroksemarang-resmi-tempuh-kasasi. diakses pada tanggal 21 November 2018
} 
Berdasarkan uraian latar belakang diatas, ada beberapa permasalahan yang akan diteliti dan dirumuskan sebagai berikut :

1. Bagaimana proses ganti kerugian terhadap pengadaan tanah untuk pembangunan kepentingan umum in casu pembangunan pelebaran jalan Kampung Tambaklorok, Kota Semarang berdasarkan UU No. 2 Tahun 2012 ?

2. Bagaimana model upaya hukum oleh pemilik yang keberatan menerima ganti kerugian dalam pengadaan tanah untuk kepentingan umum bagi pembangunan pelebaran jalan Kampung Tambaklorok, Kota Semarang ?

3. Apakah proses penyelesaian dengan upaya hukum kasasi terhadap ganti kerugian dalam pengadaan tanah untuk kepentingan umum bagi pembangunan in casu pelebaran jalan Kampung Tambaklorok, Kota Semarang merupakan solusi terbaik untuk mendapatkan keadilan bagi pemegang hak atas tanah ?

\section{B. METODE}

Metode pendekatan yang digunakan dalam penelitian ini adalah pendekatan yuridis empiris. Pendekatan yuridis dimaksudkan bahwa penelitian ini ditinjau dari peraturan peraturan yang merupakan data sekunder dan pendekatan empiris yaitu penelitian hukum yang mempergunakan data primer. ${ }^{7}$ Jadi, pendekatan yuridis empiris merupakan suatu cara/prosedur yang digunakan untuk memecahkan masalah dengan menggunakan penelitian terhadap data primer, yang fokus penelitiannya menekankan pada sesuatu kenyataan hukum dalam masyarakat. Dalam penelitian ini meninjau dan melihat serta menganalisis permasalahan "Proses Upaya Hukum Kasasi oleh Pemilik Tanah terhadap Ganti Kerugian dalam Pengadaan Tanah Bagi Pelaksanaan Pembangunan untuk Kepentingan Umum (Studi Kasus Pembangunan Jalan Tambaklorok, Kota Semarang).” Karena itu pendekatan yang dikembangkan adalah menggambarkan peraturan perundang - undangan yang berlaku dikaitkan praktek pelaksanaan hukum positif. ${ }^{8}$ Penelitian ini dilaksanakan melalui wawancara untuk memperoleh data primer yaitu data yang diperoleh langsung dari penelitian lapangan yang berasal dari narasumber terhadap Pejabat Pelaksana Teknis Kegiatan (PPTK) Dinas Pekerjaan Umum Kota Semarang, Advokat Rajendra \& Patners selaku Kuasa Hukum Pihak yang Berhak dan Pihak yang Berhak mengajukan upaya hukum kasasi terhadap besarnya ganti kerugian yang tidak sesuai.

\section{HASIL DAN PEMBAHASAN}

\section{A. Proses Pemberian Ganti Kerugian dalam Pembangunan Pelebaran Jalan Kampung Tambaklorok, Kota Semarang}

Pemberian ganti kerugian tersebut sudah dilakukan berdasarkan Undang-Undang Nomor 2 Tahun 2012 tentang Pengadaan Tanah Bagi Pembangunan Untuk Kepentingan Umum dan Peraturan Presiden Nomor 71 Tahun 2012 tentang Penyelenggaraan Pengadaan Tanah Bagi Pembangunan untuk Kepentingan Umum. Namun pada pelaksanaanya terdapat beberapa tahapan dalam Pengadaan Tanah yang tidak dilaksanakan sesuai dengan Peraturan Perundang-undangan. Hal ini

\footnotetext{
7 Ronny Hanitijo Soemitro, Metodologi Penelitian Hukum dan Jurimetri, (Jakarta: Ghalia Indonesia, 1988), hlm. 10.

${ }^{8}$ Ibid. hlm. 97.
} 
disebabkan oleh permasalahan yang ada pada tahap sosialisasi, tahap musyawarah penetapan ganti kerugian dan penitipan ganti kerugian.

Terhadap permasalahan pertama, pada tahap sosialisasi Panitia Pengadaan Tanah seharusnya melibatkan tokoh masyarakat dan masyarakat yang terkena dampak pengadaan tanah karena hal tersebut sangat menentukan besarnya bentuk ganti kerugian yang akan diterima oleh warga yang terkena dampak pengadaan tanah. Panitia Pelaksana Pengadaan Tanah seharusnya tidak hanya melaksanakan berdasarkan peraturan perundang-undangan saja, melainkan harus memperhatikan hal-hal diluar itu. Pelaksanaan Ganti Kerugian terhadap Pengadaan Tanah Bagi Pembangunan Untuk Kepentingan Umum seharusnya memperhatikan kondisi warga baik dari segi sosial, lingkungan, dan perekonomian yang ada sehingga dapat mencapai kesepakatan antara pemegang hak atas tanah yang terkena dampak pengadaan tanah dengan instansi yang memerlukan tanah. Hal tersebut sesuai asas kesepakatan dan asas keterbukaan yang ada dalam Undang-Undang Nomor 2 Tahun 2012 tentang Pengadaan Tanah Bagi Pembangunan Untuk Kepentingan Umum dan Pasal 6 ayat (1) Peraturan Presiden No. 71 Tahun 2012 tentang Penyelenggaraan Pengadaan Tanah Bagi Pembangunan Untuk Kepentingan Umum.

Terhadap permasalahan kedua, pada tahap musyawarah menetapkan ganti kerugian, secara teknis, Dinas Pekerjaan Umum hanya menyerahkan sepenuhnya pada "Appraisal" (Tim Penilai Independen) dan menyampaikan hasilnya pada masyarakat. Kantor Pertanahan Kota Semarang hanya berfungsi sebagai Instansi yang melaksanakan pengukuran data pengadaan tanah, sehingga dengan alasan tersebut masyarakat menganggap bahwa ganti kerugian yang diberikan oleh Panitia Pengadaan Tanah dianggap belum adil dan tidak layak. Hal tersebut kurang diperhatikan pada tahap penyusunan dokumen pengadaan tanah. Kemudian, pihak yang berhak hanya diberikan besarnya bentuk ganti kerugian yang akan diterima dan tidak diberikan kesempatan untuk mengemukakan pendapat, sehingga pihak pemilik tanah merasa tidak ada ruang untuk bermusyawarah, dan akhirnya mengajukan keberatan terhadap besarnya nilai ganti kerugian yang ditetapkan ke pengadilan. Panitia Pengadaan Tanah (P2T) seharusnya berpedoman pada asas dan prinsip Pengadaan Tanah Bagi Pembangunan Untuk Kepentingan Umum yaitu pada asas keadilan prinsip musyawarah, prinsip ganti rugi yang layak dan adil, sehingga pihak yang berhak tidak perlu melakukan upaya hukum yang berupa keberatan di Pengadilan.

Terhadap permasalahan ketiga, berkaitan dengan penitipan ganti kerugian ini dijadikan sebagai alat untuk menentukan pilihan terakhir bagi pihak yang berhak untuk menentukan bahwa pemilik tanah memilih mengambil uang ganti kerugian atau secara sukarela melepaskan hak atas tanahnya tanpa memperoleh ganti kerugian. Hal tersebut bertentangan dengan asas-asas penguasaan hak atas tanah dalam hukum tanah nasional sebagaimana tercantum pada Undang-Undang tentang Pengadaan Tanah Bagi Pelaksanaan Pembangunan untuk Kepentingan Umum. Maka, menurut penulis pelaksanaan proses ganti kerugian dalam pengadaan tanah untuk pembangunan pelebaran jalan hingga pemberian ganti kerugian Kampung Tambaklorok, Kelurahan Tanjung Mas, Kota Semarang belum terlaksana sesuai dengan peraturan perundang-undangan dan penitipan ganti kerugian di Pengadilan Negeri Semarang sebagai jalan pintas untuk mempercepat proses saja. 


\section{B. Model Upaya Hukum oleh Pemilik Tanah terhadap Ganti Kerugian dalam Pembangunan Jalan Kampung Tambaklorok, Kota Semarang}

Pemilik tanah yang tidak sepakat dengan besarnya ganti kerugian mengajukan keberatan ke Pengadilan Negeri Semarang dan Putusan Pengadilan Negeri tidak menerima keberatan pemohon. Maka upaya hukum berikutnya bukanlah Banding ke Pengadilan Tinggi sebagaimana dalam Hukum Acara Perdata, namun diatur hukum acara secara khusus dalm UU Pengadaan Tanah, yaitu kasasi ke mahkamah Agung. Proses diawali dari pihak pemilik tanah yang menolak bentuk dan/atau besarnya ganti kerugian yang ditetapkan oleh appraisal ke Pengadilan Negeri. Maka, berdasarkan peraturan perundang-undangan pihak pemilik tanah mengajukan keberatan paling lama 14 (empat belas) hari kerja terhitung setelah musyawarah dilakukan dalam bentuk permohonan gugatan ke pengadilan negeri setempat. Putusan Pengadilan yang dijatuhkan oleh hakim belum memiliki kekuatan hukum tetap, sehingga dapat dilakukan upaya hukum kasasi. Adapun data pemilik tanah yang mengajukan keberatan atas ganti kerugian ke Pengadilan Negeri Semarang sbb:

Tabel 1. Data Hak Atas Tanah dan Ganti Kerugian yang ditetapkan

\begin{tabular}{|c|c|c|c|c|}
\hline \multirow[t]{2}{*}{ No } & \multirow[t]{2}{*}{ Nama } & \multicolumn{2}{|c|}{ Status } & \multirow{2}{*}{$\begin{array}{c}\text { Nilai Total } \\
\text { Pergantian Wajar }\end{array}$} \\
\hline & & Sertipikat/TN & Terkena & \\
\hline 1 & $\begin{array}{ll}\text { Drs. } & \text { Ahmad } \\
\text { Suhaili } & \end{array}$ & $\begin{array}{c}\text { HM } \\
\text { Tanah Negara }\end{array}$ & $\begin{array}{c}61 \mathrm{~m}^{2} \\
156,5 \mathrm{~m}^{2}\end{array}$ & Rp. 688.958.000,- \\
\hline 2 & Achmad Busairi & $\mathrm{HM}$ & $71 \mathrm{~m}^{2}$ & Rp. 414.652.000,- \\
\hline 3 & Muchlasin & $\begin{array}{c}\text { HM } \\
\text { Tanah Negara }\end{array}$ & $\begin{array}{l}75 m^{2} \\
60 m^{2}\end{array}$ & Rp. 417.538.000,- \\
\hline 4 & Achmadi & $\begin{array}{c}\text { HM } \\
\text { Tanah Negara }\end{array}$ & $\begin{array}{l}47 \mathrm{~m}^{2} \\
14 \mathrm{~m}^{2}\end{array}$ & Rp. 244.414.000,- \\
\hline
\end{tabular}

Sumber : Salinan Penetapan No. 374/Pdt.P/2018/PN. Semarang

Kemudian Pihak pemilik tanah yang berhak mengajukan besarnya ganti kerugian pada Instansi yang melaksanakan Pengadaan Tanah dengan perincian sbb:

Ganti Kerugian Fisik (Materiil)

\begin{tabular}{|c|l|l|c|}
\hline No & \multicolumn{1}{|c|}{ Nama Pemilik } & \multicolumn{1}{|c|}{ Alamat Pemilik } & $\begin{array}{c}\text { Nilai Ganti } \\
\text { Kerugian }\end{array}$ \\
\hline 1 & Drs. Ahmad Suhaili & $\begin{array}{l}\text { Tambak Mulyo, RT.004 } \\
\text { RW.014, Kelurahan Tanjung } \\
\text { Mas, Kecamatan Semarang } \\
\text { Utara, Kota Semarang }\end{array}$ & $\begin{array}{c}\text { Rp. } \\
1.000 .000 .000,-\end{array}$ \\
\hline 2 & Ahmad Busairi & $\begin{array}{l}\text { Tambak Mulyo, RT.005 } \\
\text { RW.014, Kelurahan Tanjung } \\
\text { Mas, Kecamatan Semarang }\end{array}$ & \\
& & Rtara, Kota Semarang & \\
\hline
\end{tabular}




\begin{tabular}{|c|l|l|l|}
\hline 3 & Achmadi & Jalan Ngablak Indah RT.001 & Rp. 450.000.000,- \\
& & RW.004, Kelurahan & \\
& & Bangetayu r Kulon, \\
& Kecamatan Genuk, Kota & \\
& & Semarang & \\
\hline 4 & Muchlasin & Tambak Mulyo RT.008 & Rp. 700.000.000,- \\
& RW.012, Kelurahan Tanjung & \\
& & Mas, Kecamatan Semarang & \\
& & Utara, Kota Semarang & \\
\hline
\end{tabular}

Sumber : Salinan Penetapan No. 374/Pdt.P/2018/PN. Semarang

Ganti Kerugian Non Fisik (Immateriil)

\begin{tabular}{|c|c|c|c|}
\hline No & Nama Pemilik & Alamat Pemilik & $\begin{array}{l}\text { Nilai Ganti } \\
\text { Kerugian }\end{array}$ \\
\hline 1 & Drs. Ahmad Suhaili & $\begin{array}{l}\text { Tambak Mulyo, RT.004 } \\
\text { RW.014, Kelurahan Tanjung } \\
\text { Mas, Kecamatan Semarang } \\
\text { Utara, Kota Semarang }\end{array}$ & $\begin{array}{c}\text { Rp. } \\
1.000 .000 .000,-\end{array}$ \\
\hline 2 & Ahmad Busairi & $\begin{array}{l}\text { Tambak Mulyo, RT.005 } \\
\text { RW.014, Kelurahan Tanjung } \\
\text { Mas, Kecamatan Semarang } \\
\text { Utara, Kota Semarang }\end{array}$ & Rp 500.000.000,- \\
\hline 3 & Achmadi & $\begin{array}{lr}\text { Jalan Ngablak Indah RT.001 } \\
\text { RW.004, } & \text { Kelurahan } \\
\text { Bangetayu } & \text { Kulon, } \\
\text { Kecamatan } & \text { Genuk, Kota } \\
\text { Semarang } & \\
\end{array}$ & Rp. 200.000.000,- \\
\hline 4 & Muchlasin & $\begin{array}{l}\text { Tambak Mulyo RT.008 } \\
\text { RW.012, Kelurahan Tanjung } \\
\text { Mas, Kecamatan Semarang } \\
\text { Utara, Kota Semarang }\end{array}$ & Rp. 300.000.000,- \\
\hline
\end{tabular}

Sumber : Salinan Penetapan No. 374/Pdt.P/2018/PN. Semarang

Menurut penulis proses upaya hukum kasasi ini tidak terdapat kendala baik bagi kuasa hukum para pihak maupun pemegang hak atas tanah yang mengajukan upaya hukum kasasi. Proses upaya hukum kasasi sudah berjalan sesuai dengan Peraturan Mahkamah Agung No. 3 Tahun 2016 tentang Tata Cara Pengajuan Keberatan terhadap Ganti Kerugian Dalam Pengadaan Tanah Untuk Kepentingan Umum. Namun, terhadap putusan yang dijatuhkan dan hal-hal yang dijelaskan dalam Memori Kasasi maka hakim sebelum menjatuhkan putusan, hakim seharusnya perlu menggali dan mempelajari kronologi sengketa, tenggang waktu pengajuan keberatan, alasan-alasan keberatan, dan fakta persidangan.

Pertama, terhadap tenggang waktu pengajuan keberatan yang diajukan oleh pemohon. Pada dasar-dasar pengajuan upaya hukum kasasi yang diajukan oleh pemegang hak atas tanah terhadap putusan hakim yang dijatuhkan dengan pertimbangan tidak dipenuhinya ketentuan syarat formil yang diajukan oleh pemohon dalam hal ini pemegang hak atas tanah yang tidak menerima besarnya ganti kerugian. Tenggang 
waktu pengajuan keberatan yang intinya menjelaskan, pemohon merasa bahwa Panitia Pengadaan Tanah belum pernah memberikan informasi mengenai hasil kesepakatan dalam musyawarah maupun secara resmi menerima Berita Acara kesepakatan dalam musyawarah yang berupa isi dari Berita Acara kesepakatan tersebut memuat tentang adanya persetujuan maupun ketidaksetujuan pihak yang berhak.

Terhadap alasan-alasan keberatan yang diajukan oleh pemegang hak atas tanah, yang memuat kondisi sosial, ekonomi, dan budaya pemegang hak atas tanah dan besarnya nilai ganti kerugian yang diajukan sesuai harga pasar baik secara fisik maupun non fisik, maka hakim dalam menjatuhkan putusan dalam persoalan ini kurang mempertimbangkan serta mempelajari alasan-alasan keberatan yang diajukan oleh pemegang hak atas tanah.

Berkaitan dengan fakta persidangan, dengan memperhatikan itikad dari salah satu Termohon yaitu Kantor Pertanahan Kota Semarang yang tidak pernah menghadiri persidangan, hal tersebut dapat memunculkan perbedaan pemahaman oleh hakim yang menjatuhkan putusan pengadilan berpengaruh pada saat hakim melakukan pertimbangan yang hanya dihadiri oleh salah satu pihak termohon yaitu Dinas Pekerjaan Umum Kota Semarang.

Maka dapat dinyatakan bahwa proses pengajuan upaya hukum kasasi terhadap ganti kerugian dalam pengadaan tanah untuk pembangunan pelebaran jalan Kampung Tambaklorok, Kota Semarang sudah sesuai dengan ketentuan peraturan perundangundangan yang berlaku. Namun substansi pertimbangan hakim dalam menjatuhkan Penetapan Pengadilan Negeri Semarang No. 374/Pdt.P/2018/PN. Semarang serta Memori Kasasi yang diajukan terhadap putusan tersebut, belum menyelesaikan sengketa pertanahan dalam hal mengenai besaran ganti kerugian yang ditentukan antara pemegang hak atas tanah dengan instansi yang membutuhkan tanah, karena itu harapan terakhir adalah putusan Kasasi MA yang sampai saat ini masih dalam proses di Mahkamah Agung RI.

\section{Solusi terhadap Proses Upaya Hukum Kasasi terhadap Ganti Kerugian dalam pembangunan Pelebaran Jalan Kampung Tambaklorok, Kota Semarang}

Menurut penulis meskipun Panitia Pengadaan Tanah pada umumnya sudah melaksanakan Pengadaan Tanah terhadap pembangunan pelebaran jalan Kampung Tambaklorok, Kota Semarang sesuai dengan peraturan perundang-undangan yang berlaku. Apabila seluruh prosedur pelaksanaan pengadaan tanah sepenuhnya dilaksanakan sesuai ketentuan yang ada, maka masyarakat bersedia melepaskan tanah yang digunakan untuk kebutuhan pembangunan pelebaran jalan. Karena warga juga yang akan merasakan dampak positif terhadap kehidupan mereka baik usaha pekerjaan maupun kondisi perekonomian mereka. Pelaksanaan Pemberian Ganti Kerugian dalam Pengadaan Tanah Untuk Kepentingan Umum pada dasarnya, pemerintah dalam memberdayakan potensi daerah dalam hal melakukan pembangunan dengan memberikan kewenangan bagi instansi yang membutuhkan tanah tidak terlepas dari peran dan partipasi masyarakat terutama para pihak yang terkena pembangunan pelebaran jalan.

Oleh karena itu, dengan melibatkan para pihak dalam proses pengadaan tanah dalam hal menentukan besarnya nilai ganti kerugian maka pembangunan untuk 
kepentingan umum dapat terlaksana dan dapat menjamin kesejahteraan kehidupan masyarakat, sehingga masyarakat tidak mencari keadilan melalui pengadilan hingga menempuh upaya hukum yang final yaitu kasasi, karena masyarakat yang mengetahui apa yang mereka butuhkan.

Upaya hukum kasasi yang diajukan pihak yang berhak merupakan upaya hukum terakhir untuk mendapatkan keadilan apabila Mahkamah Agung tidak menjatuhkan putusan yang egaliter terhadap pihak yang berhak dan instansi yang melaksanakan pengadaan tanah maka selesailah upaya mencari keadilan ini. Karena upaya hukum ini merupakan final dan putusan yang dijatuhkan bersifat mengikat. Apabila hakim Mahkamah Agung menjatuhkan putusan kasasi masih bersifat sepihak, maka visi Mahkamah Agung untuk menerapkan asas Peradilan yang cepat, sederhana, serta menjadi Lembaga Peradilan yang Agung, menjadi jauh dari harapan masyarakat.

Meskipun undang-undang telah memberi peluang model upaya hukum bagi para pihak, namun upaya terbaik yang dapat ditempuh oleh pemilik tanah dan instansi yang melaksanakan pengadaan tanah agar mendapatkan keadilan yaitu dengan melakukan musyawarah untuk mendapatkan mufakat. Agar dapat mengatasi sengketa pertanahan sebelum memasuki lingkungan pengadilan, melalui mediasi secara persuasif sehingga pihak pemilik tanah dan panitia mendapatkan solusi yang memenuhi rasa keadilan bagi pemegang hak atas tanah.

\section{KESIMPULAN}

1. Proses Pemberian Ganti Kerugian dalam Pembangunan Pelebaran Jalan Kampung Tambaklorok, Kota Semarang belum selesai sampai saat ini, meskipun umumnya sudah sesuai dengan Undang-Undang Nomor 2 Tahun 2012 tentang Pengadaan Tanah Bagi Pembangunan Untuk Kepentingan Umum. Namun, dalam pelaksanaannya, pada tahap sosialisasi jangka waktu pelaksanaan yang dilaksanakan oleh Panitia Pengadaan Tanah mengalami keterlambatan. Kemudian, pihak yang berhak tidak diberikan kesempatan untuk mengemukakan pendapat dalam musyawarah penetapan ganti kerugian. Hal tersebut yang menyebabkan pihak yang berhak meminta kompensasi terhadap ganti kerugian yang lebih layak.

2. Upaya Hukum dari Penetapan Pengadilan Negeri Semarang No. 374/Pdt.P/2018/PN. Semarang dengan alasan tidak dipenuhinya syarat formil berupa tidak adanya berita acara kesepakatan musyawarah penetapan ganti kerugian yang dimiliki oleh pemilik tanah sebagaimana dimaksud pada Pasal 6 ayat (1) huruf d Peraturan Mahkamah Agung No. 3 Tahun 2016 dilakukan tidak dengan Banding namun Kasasi, sesuai dengan Peraturan Mahkamah Agung No. 3 Tahun 2016 tentang Tata Cara Pengajuan Keberatan dan Penitipan Ganti Kerugian Dalam Pengadaan Tanah Bagi Pembangunan Untuk Kepentingan Umum.

3. Upaya Hukum Kasasi terhadap Ganti Kerugian dalam pembangunan Pelebaran Jalan Kampung Tambaklorok, Kota Semarang merupakan upaya hukum yang pertama dan terakhir bagi pemilik tanah untuk mendapatkan keadilan, apabila Mahkamah Agung tidak memberikan putusan yang egaliter bagi para pihak maka selesailah harapan pencari keadilan, karena upaya hukum ini merupakan final dan putusan yang dijatuhkan bersifat mengikat. 


\section{E. SARAN}

1. Bagi Pemerintah

Badan Pertanahan Nasional Kota Semarang dan Dinas Pekerjaan Umum Kota Semarang selaku instansi pemerintah yang membutuhkan tanah, seharusnya menjadi garda terdepan dalam mensukseskan pengadaan tanah. Terhadap permasalahan pengadaan tanah, pertama instansi yang membutuhkan tanah untuk pembangunan bagi kepentingan umum, melakukan penelitian dan kajian secara tepat dan cermat dalam menentukan kepastian data yang akurat dalam dokumen pengadaan tanah DED (Detail Engineering Design). Kedua, bagi Panitia Pengadaan Tanah terhadap Berita Acara kesepakatan seharusnya tetap diinformasikan kepada para pihak yang berhak pada saat musyawarah penetapan ganti kerugian, meskipun belum adanya kesesuaian atau dengan kata lain kesepakatan yang terjadi antara pemilik tanah/pihak yang berhak dengan pihak yang membutuhkan tanah tersebut karena pentingnya Berita Acara kesepakatan tersebut guna dijadikan dasar hukum bagi pihak-pihak yang masih belum mencapai kata sepakat atau masih adanya keberatan terhadap hasil dari penilaian yang diberikan oleh penilai besaran ganti kerugian.

\section{Bagi Penegak Hukum}

Terhadap sengketa pertanahan, upaya yang dapat dilakukan oleh penegak hukum yaitu pertama, sebelum menjatuhkan putusan, hakim dalam melakukan pertimbangan hukum tidak hanya memperhatikan dari segi peraturan perundangundangan saja. Hakim seyogyanya menggali nilai-nilai hukum yang hidup di masyarakat sebelum menjatuhkan putusan. Selain itu hakim sebaiknya mempertimbangkan kronologi perkara, alat bukti dalam fakta persidangan, dan klarifikasi kembali kepada pihak pemohon keberatan.

Kedua, proses putusan kasasi yang dilakukan oleh Mahkamah Agung menghabiskan waktu yang lama untuk mengkaji ulang putusan hakim yang sebelumnya, maka Lembaga Pengadilan ke depan perlu memisahkan sengketa Pertanahan terhadap sengketa hukum lainnya melalui Pengadilan khusus dalam lingkungan peradilan umum yaitu Pengadilan Pertanahan untuk menuntaskan permasalahan hukum di bidang pertanahan baik perdata maupun pidana. 


\section{F. DAFTAR PUSTAKA}

\section{A. Buku}

Supomo. (1967) Hukum Acara Perdata Pengadilan Negeri. Pradnjaparamita : Jakarta.

Soemitro, Hanitijo Ronny. (1988) Metodologi Penelitian Hukum dan Jurimetri, Ghalia Indonesia : Jakarta.

Soetianto, Retnowulan dan Oeripkartawinata, Iskandar. (1997) Hukum Acara Perdata Dalam Teori dan Praktek. CV. Mandar Maju : Jakarta.

Zulaika, Erni. (2000) Pelaksanaan Azas Peradilan Cepat Dalam Pemeriksaan Perkara Perdata Pada Tingkat Banding.

Waluyo, Bambang. (2002) Penelitian Hukum dalam Praktek. Sinar Grafika : Jakarta.

Soimin, Soedharyo. (2004) Status Hak dan Pembebasan Tanah, Edisi. 2 Cet. 2 Sinar Grafika : Jakarta.

Harsono, Boedi. (2005) Hukum Agraria Indonesia, Sejarah Pembentukan UndangUndang Pokok Agraria, Isi dan Pelaksanaannya. Jilid 1 Hukum Tanah Nasional. Edisi Revisi. Penerbit Djambatan : Jakarta.

Sutedi, Adrian. (2007) Implementasi Prinsip Kepentingan Umum Dalam Pengadaan Tanah untuk Pembangunan, Sinar Grafika : Jakarta.

Limbong, Benhard. (2011) Pengadaan Tanah Untuk Pembangunan Regulasi Kompensasi Penegakan Hukum, Margaretha Pustaka : Jakarta Selatan.

Dewi, Santi Gangga IGA. (2016) Hukum Agraria. Fakultas Hukum Universitas Diponegoro : Semarang.

Sarwono. (2011) Hukum Acara Perdata Teori dan Praktik. Sinar Grafika : Jakarta.

\section{B. Undang-Undang}

Undang - Undang Pokok Agraria No. 5 Tahun 1960 tentang UUPA

Undang-Undang Nomor 20 Tahun 1961 tentang Pencabutan Hak Atas Tanah Dan Benda-benda yang ada di atasnya.

Undang - Undang No. 2 Tahun 2012 tentang Pengadaan Tanah Bagi Pelaksanaan Pembangunan untuk Kepentingan Umum.

Peraturan Presiden Nomor 71 Tahun 2012 tentang Penyelenggaran Pengadaan Tanah Bagi Pembangunan untuk Kepentingan Umum.

Peraturan Mahkamah Agung Nomor 3 Tahun 2016 tentang Tata Cara Pengajuan Keberatan Dan Penitipan Ganti Kerugian Ke Pengadilan Negeri Dalam Pengadaan Tanah Untuk Kepentingan Umum. 


\section{Jurnal}

Dwi Fratmawati, Pengadaan Tanah Bagi Pelaksanaan Pembangunan Untuk Kepentingan Umum Di Semarang (Studi Kasus Pelebaran Jalan Raya Ngaliyan Mijen) (Semarang : UNDIP. 2006)

Sonny Djoko Marlijanto, "Konsinyasi Ganti Rugi dalam Pengadaan Tanah untuk Kepentingan Umum (Studi Pengadaan Tanah untuk Pembangunan Proyek Jalan TOL Semarang - Solo Kabupaten Semarang)" (Semarang: Fakultas Hukum Universitas Diponegoro. 2010).

Aghisni Panji Hadi Kusumo, "Tinjauan Yuridis Terhadap Substansi Undang - Undang Nomor 2 Tahun 2012 tentang Pengadaan Tanah untuk Kepentingan Umum yang Mengalami Judicial Review". Diponegoro Law Review. Vol. 1. No. 2. (Semarang: Fakultas Hukum Universitas Diponegoro. 2013).

Bambang Istijono, Lahan Menjadi aktor Penghambat dalam Pelaksanaan Pembangunan untuk Kepentingan Umum. Jurnal Rekayasa Sipil. Vol. 10 No. 2. Oktober 2014. (Padang: Fakultas Teknik. Universitas Andalas. 2014).

Sahnan. Penerapan Prinsip Keadilan Dalam Pengadaan Tanah Bagi Pembangunan Untuk Kepentingan Umum. Dosen Bidang Pertanahan. Jurnal IUS Kajian Hukum dan Keadilan Vol. III No. 09. Desember 2015 (Mataram: Fakultas Hukum. Universitas Mataram. 2015).

Urip Santoso, Penyelesaian Sengketa dalam Pengadaan untuk Kepentingan Umum. Jurnal Perspektif. Vol. 21 No. 1. September 2016. (Surabaya: Fakultas Hukum Universitas Airlangga. 2016).

\section{Website}

http://jateng.tribunnews.com/2018/10/31/warga-terdampak-pembangunan-kampungbahari-tambaklorok-semarang-resmi-tempuh-kasasi. diakses pada tanggal 21 November 2018.

https://kepaniteraan.mahkamahagung.go.id/index.php/prosedur-berperkara/prosedurkasasi diakses pada tanggal 28 Desember 2018.

http://jateng.tribunnews.com/2019/03/26/pembangunan-kampung-bahari-tambakloroksemarang-masih-terkendala-pembebasan-lahan diakses pada tanggal 1 April 2019.

Pasaribu, Ignasio Ivor. 2019. Penilaian Ganti Kerugian Dalam Pengadaan Tanah Bagi Pembangunan Untuk Kepentingan Umum.

https://www.hukumproperti.com/articles/penilaian-ganti-kerugian-dalam-pengadaantanah-bagi-pembangunan-untuk-kepentingan-umum/ diakses pada tanggal 22 April 2019. 
